\title{
ANALISIS FAKTOR - FAKTOR BAURAN PEMASARAN TERHADAP KEPUTUSAN PEMBELIAN DAGING AYAM DI PASAR SWALAYAN FRESH MART BAHU KECAMATAN MALALAYANG KOTA MANADO
}

\author{
Randy Taroreh, M. L. Rundengan*, J. K. J. Kalangi, Franky N. S. Oroh.
}

Fakultas Peternakan Universitas Sam Ratulangi, Manado, 95115

\begin{abstract}
ABSTRAK
Ayam ras pedaging merupakan jenis ternak yang sangat populer di seluruh dunia khususnya sebagai sumber bahan makanan bergizi tinggi untuk memenuhi kebutuhan protein bagi tubuh. Upaya yang dapat dilakukan pasar swalayan untuk mengatasi ketatnya persaingan adalah dengan menetapkan strategi pemasaran. Salah satu strategi yang penting adalah bauran pemasaran. Strategi bauran pemasaran dilakukan semata - mata bertujuan untuk mendapatkan kepuasan yang di inginkan konsumen. Penelitian ini bermaksud ingin mengetahui faktor - faktor apa yang mempengaruhi konsumen dalam melakukan keputusan pembelian daging ayam ras di pasar swalayan Fresh Mart Bahu. Responden yang diambil sebanyak 100 orang dengan metode pengambilan sampel menggunakan accidental sampling. Proses analisis menggunakan program SPSS for windows versi 23. Data dianalisis dengan menggunakan analisis faktor kemudian dilanjutkan dengan analisis regresi berganda untuk mengetahui seberapa besar pengaruh faktor - faktor bauran pemasaran terhadap keputusan pembelian. Faktor - faktor yang mempengaruhi keputusan pembelian yaitu warna daging $\left(X_{1}\right)$, harga terjangkau $\left(X_{2}\right)$, lokasi strategis $\left(\mathrm{X}_{3}\right)$, dan materi iklan $\left(\mathrm{X}_{4}\right)$. Faktor yang paling dominan dalam menentukan keputusan pembelian adalah warna daging $\left(\mathrm{X}_{1}\right)$ dengan nilai koefisien regresi terbesar yaitu 0,725 .
\end{abstract}

*Korespondensi (Corresponding Author):

Email: meiskerundengan@unsrat.ac.id
Kata kunci: Daging ayam (broiler), bauran pemasaran, keputusan pembelian.

\begin{tabular}{lrr}
\multicolumn{4}{c}{ ABSTRACT } \\
ANALYSIS OF MARKETING & MIXED \\
FACTORS ON & BROILER & MEAT \\
PURCHASING & DECISION & AT \\
PRESHMART SUPER STORE & BAHU, \\
MALALAYANG & DISTRICT & OF \\
MANADO CITY. & Broiler meats & were
\end{tabular}
categorized into popular high nutrient food product to supply protein needs of human being. The activities applied by the super store to overcome the high competition supplying consumers were to define the marketing strategy. A certain important strategy was mixed marketing. Strategy of mixed marketing was only applied to obtain the satisfaction wanted by consumers. The objective of this study was to evaluate factors affecting consumers to decide their decision on broiler meat purchasing at the fresh-mart super store Bahu, Mando. A total of hundred purchasers were chosen to be samples using accidental sampling method. Analysis was done by SPSS program for Windows version 23 . Data were analyzed by factors analysis model, continued by multiple regression to define the effects of factors of mixed marketing on purchasing decision by consumers. The factors affecting purchasing decision by consumers were meat color $\left(\mathrm{X}_{1}\right)$, reached price $\left(\mathrm{X}_{2}\right)$, strategic location $\left(\mathrm{X}_{3}\right)$, and advertising material $\left(\mathrm{X}_{4}\right)$. The dominant factor affecting purchasing decision was meat color $\left(\mathrm{X}_{1}\right)$ with the highest regression coefficient of 0.725 .

Key Word: Broiler meat, mixed marketing, consumer purchasing decision. 


\section{PENDAHULUAN}

Peternakan merupakan sektor yang berperan dalam pemenuhan kebutuhan sumber protein hewani masyarakat Indonesia. sumber protein hewani asal ternak dapat dibagi kedalam beberapa kelompok yaitu yang berasal dari kelompok ternak besar seperti sapi dan kerbau, kelompok ternak kecil seperti kambing, domba, dan babi, kelompok unggas seperti ayam dan itik serta kelompok hasil-hasil ternak seperti susu dan telur (Setiawan. 2006).

Masyarakat dalam mengkonsumsi daging ayam selalu memilih diantara 3 jenis daging ayam tersebut yang tersedia di pasar. perbedaan dari sisi citarasa dan harga merupakan salah satu pertimbangan masyarakat dalam mengkonsumsi daging ayam dan salah satu daging ayam yang digemari masyarakat adalah ayam pedaging (broiler chicken). ayam pedaging (broiler chicken) dijual di berbagai tempat di Kota Manado. pasar swalayan yang tersebar di setiap daerah di Kota Manado dipastikan menjual/menawarkan ayam pedaging atau yang lebih dikenal masyarakat dengan daging ayam potong; selain di pasar swalayan, daging ayam ras juga tersedia di pasar tradisional yang ada di Kota Manado. Upaya yang dapat dilakukan pasar swalayan untuk mengatasi ketatnya persaingan adalah dengan menetapkan strategi pemasaran. Ada berbagai strategi pemasaran yang dapat digunakan seperti segmentasi pasar, strategi menganalisis perilaku pelanggan, dan strategi bauran pemasaran. salah satu strategi yang penting dan semestinya mendapat perhatian adalah bauran pemasaran. Bauran pemasaran terdiri dari produk, harga, distribusi dan promosi. Strategi bauran pemasaran dilakukan semata - mata bertujuan untuk mendapatkan kepuasan yang diinginkan konsumen. Kepuasan konsumen merupakan perioritas utama pada keputusan pembelian oleh konsumen dari tingkat kepentingan dan harapan pelanggan (Hatane, 2006). Tujuan penelitian ini untuk mengetahui faktor faktor yang berpengaruh terhadap keputusan pdembelian daging ayam di swalayan Fresh Mart Bahu Manado.

\section{METODE PENELITIAN}

Penelitian ini dilaksanakan di pasar swalayan Fresh Mart Bahu pada bulan Juli sampai dengan bulan Agustus 2018. Menurut Sugiyono (2012) berdasarkan sumbernya, data dibedakan menjadi dua yaitu data primer dan sekunder. Data primer merupakan sumber data yang diperoleh secara (accidental sampling) langsung dari responden dilapangan. Data sekunder, 
merupakan data yang sudah tersedia dari studi literatur, buku dan jurnal ilmiah. Metode yang digunakan adalah dengan menggunakan kuesioner, yaitu teknik pengumpulan data yang dilakukan dengan cara memberi pertanyaan tertulis kepada responden untuk di jawab oleh responden yang membeli daging ayam ras di pasar Menurut Purba dalam Kharis (2011). Teknik pengambilan sampel menggunakan accidental sampling dengan cara memperoleh data dari responden yang ditemui secara langsung saat membeli daging ayam ras di pasar swalayan Fresh Mart Bahu sebanyak 100 responden. Metode analisis data menggunakan analisis faktor untuk penyederhanaan data dengan melihat interpendensi beberapa variabel sehingga ditemukan beberapa variabel yang mewakili variabel - variabel sebelumnya (Santoso. 2004). Kemudian dilanjutkan dengan menggunakan analisis regresi berganda untuk mengetahui pengaruh satu atau lebih variabel bebas terhadap satu variabel tidak bebas dengan menggunakan rumus persamaan regresi linier berganda (Siregar, 2013).

$\mathrm{Y}=a+b_{1} \mathrm{X}_{1}+\mathrm{b}_{2} \mathrm{X}_{2}+b_{3} \mathrm{X}_{3}+\mathrm{b}_{4} \mathrm{X}_{4}+e$

Keterangan :

\begin{tabular}{|c|c|}
\hline Y & $=$ keputusan pembelian \\
\hline$X_{1}$ & $=$ produk \\
\hline$X_{2}$ & $=$ harga \\
\hline$X_{3}$ & $=$ tempat \\
\hline$X_{4}$ & $=$ promosi \\
\hline & $=$ nilai konstanta \\
\hline $\begin{array}{l}\mathrm{b}_{1}, \mathrm{~b}_{2}, \mathrm{~b}_{3}, \mathrm{~b}_{4} \\
\mathrm{e}\end{array}$ & $\begin{array}{l}=\text { koefisien regresi } \\
=\text { nilai error }\end{array}$ \\
\hline
\end{tabular}

Indikator - indikator tersebut diukur dengan skala penilaian likert yang memiliki lima tingkat perferensi jawaban yang masing - masing mempunyai bobot skor 1 - 5 (Sugiyono. 2012). Selanjutnya di analisis dengan menggunakan Uji F (simultan) dan Uji $T$ (parsial). Cara menganalisis data menggunakan aplikasi SPSS Versi 23.

HASIL DAN PEMBAHASAN

\section{Karakteristik responden}

Tabel 1. Karakteristik Responden Berdasarkan Jenis Kelamin

\begin{tabular}{lcc}
\hline JenisKelamin & Jumlah $(\mathbf{O r g})$ & Persentase $(\%)$ \\
\hline Laki - laki & 23 & 23 \\
Perempuan & 77 & 77 \\
Jumlah & 100 & 100 \\
\hline
\end{tabular}


Tabel 2. Karakteristik Responden Berdasarkan Umur

\begin{tabular}{lcc}
\hline Umur & Jumlah $(\mathbf{O r g})$ & Persentase $(\%)$ \\
\hline$<20$ Tahun & 9 & 9 \\
$21-30$ Tahun & 33 & 33 \\
$31-40$ Tahun & 34 & 34 \\
$>40$ Tahun & 24 & 24 \\
Jumlah & 100 & 100 \\
\hline
\end{tabular}

Tabel 3. Karakteristik Respoden Menurut Jenis Pekerjaan

\begin{tabular}{lcc}
\hline Pekerjaan & Jumlah $(\mathbf{O r g})$ & Persentase $\mathbf{( \% )}$ \\
\hline ASN (Aparatur Sipil Negara) & 31 & 31 \\
Pegawai swasta & 29 & 29 \\
Pelajar/Mahasiswa & 17 & 17 \\
Wiraswasta & 23 & 23 \\
Jumlah & 100 & 100 \\
\hline
\end{tabular}

Tabel 4. Karakteristik Menurut Jumlah Pendapatan Per Bulan

\begin{tabular}{lcc}
\hline Pendapatan per bulan & Jumlah (Org) & Persentase (\%) \\
\hline$<$ Rp 2.000.000 & 11 & 11 \\
Rp 2.000.000-2.500.000 & 22 & 22 \\
Rp 2.500.000-3.500.000 & 33 & 33 \\
$>$ Rp 3.500.000 & 34 & 34 \\
Jumlah & 100 & 100 \\
\hline
\end{tabular}

Tabel 5. Karakteristik Responden Menurut Tingkat Pendidikan

\begin{tabular}{lcc}
\hline Pendidikan & Jumlah $(\mathbf{O r g})$ & Persentase (\%) \\
\hline SMA & 43 & 43 \\
Sarjana (S1) & 57 & 57 \\
Jumlah & 100 & 100 \\
\hline
\end{tabular}


Tabel 6. Nilai Factor Loading

\begin{tabular}{|c|c|c|c|c|c|}
\hline \multicolumn{6}{|c|}{ Factor Loading } \\
\hline Faktor & Variabel & 1 & 2 & 3 & 4 \\
\hline \multirow{5}{*}{ Produk } & Aroma daging & 0.897 & & & \\
\hline & Warna daging & 0.909 & & & \\
\hline & Kebersihan daging & 0.602 & & & \\
\hline & Kemasan daging & 0.603 & & & \\
\hline & Potongan daging & 0.500 & & & \\
\hline \multirow{3}{*}{ Harga } & Harga terjangkau & & 0.680 & & \\
\hline & Harga sesuai kualitas & & 0.507 & & \\
\hline & Harga bersaing & & 0.643 & & \\
\hline \multirow{3}{*}{ Tempat } & Lokasis trategis & & & 0.640 & \\
\hline & Fasilitas pendukung & & & 0.547 & \\
\hline & Letak produk & & & 0.604 & \\
\hline \multirow{3}{*}{ Promosi } & Media iklan & & & & 0.798 \\
\hline & Materi iklan & & & & 0.851 \\
\hline & Frekuensi iklan & & & & 0.665 \\
\hline
\end{tabular}

Tabel 7. Hasil Analisis Regresi Linier Berganda

\begin{tabular}{|c|c|c|c|c|c|}
\hline \multicolumn{2}{|l|}{ Variabel } & Koefisien Regresi & Std Error & $\mathrm{t}_{\text {hitung }}$ & Sig. \\
\hline \multicolumn{2}{|l|}{ (Constant) } & -1.689 & .894 & -1.890 & 0.062 \\
\hline \multicolumn{2}{|c|}{$\mathrm{X}_{1.1}$ (warna daging) } & 0.725 & .090 & 8.030 & 0.000 \\
\hline \multicolumn{2}{|c|}{$\mathrm{X}_{2.1}$ (harga yang terjangkau) } & 0.012 & .121 & 0.101 & 0.920 \\
\hline \multicolumn{2}{|c|}{$\mathrm{X}_{3.1}($ lokasi strategis $)$} & 0.052 & .067 & 0.775 & 0.540 \\
\hline \multicolumn{2}{|l|}{$\mathrm{X}_{4.1}($ materi iklan $)$} & 0.667 & .089 & 7.521 & 0.000 \\
\hline $\mathrm{R}$ & $=0,755$ & & & $\mathrm{~F}_{\text {hitung }}$ & $=31,419$ \\
\hline R Square $\left(R^{2}\right)$ & $=0,570$ & & & $\mathrm{~F}_{\text {tabel }}$ & $=2,46$ \\
\hline Signifikansi & $=0,000$ & & & $\mathrm{~T}_{\text {tabel }}$ & $=1,984$ \\
\hline
\end{tabular}

Tabel 1 Karakteristik responden berdasarkan jenis kelamin yang membeli daging ayam di pasar swalayan Fresh Mart Bahu didominasi oleh responden perempuan sebanyak 77 orang. Karena pada umumnya perempuanlah yang biasanya berbelanja dan mempunyai peran penting dalam mengatur konsumsi rumah tangga, hal ini sejalan dengan penelitian sebelumnya (Burhanudin, 2011) menyatakan bahwa responden atau konsumen yang membeli daging ayam atau sejenisnya didominasi oleh perempuan (Ibu rumah tangga) yang berbelanja bahan makanan yang akan diolah dari mentah 
hingga menjadi bahan olahan yang dapat dikonsumsi keluarga. Karena sudah terbiasa berbelanja, daging yang dipilih sangat baik.

Tabel 2 Karakteristik responden berdasarkan umur menunjukan bahwa umur responden terbanyak yaitu 31 - 40 tahun sebanyak 34 orang. Pada umur tersebut konsumen cenderung berpikir rasional dalam mengambil keputusan pembelian daging ayam ras. Hal ini sejalan dengan penelitian sebelumnya, bahwa umur merupakan salah satu faktor yang berpengaruh secara signifikan terhadap pembelian daging ( Gusti et al., 2015)

Tabel 3 Karakteristik respoden menurut jenis pekerjaan menunjukan jenis pekerjaan sebagai ASN (Aparatur Sipil Negara) yang mendominasi, yaitu sebanyak 31 orang. Hal ini sejalan dengan penelitian sebelumnya dan sejalan dengan karakteristik responden menurut jenis kelamin perempuan dimana konsumen berjenis kelamin perempuan (Ibu rumah tangga) yang biasanya bertanggung jawab terhadap pemenuhan gizi keluarga (Gusti et al., 2015).

Tabel 4 Karakteristik menurut jumlah pendapatan per bulan menunjukan bahwa yang membeli daging ayam ras didominasi oleh yang berpendapatan > Rp. 3.500.000, sebanyak 34 orang. Hal ini mengindikasikan konsumen yang membeli daging ayam ras berpenghasilan cukup.

Tabel 5 Responden menurut tingkat pendidikan S1 yang mendominasi sebanyak 57 orang. Sayuti dan Efendi (2004) Menunjukan bahwa semakin tinggi tingkat pendidikan seseorang akan sangat berpengaruh terhadap posisi sosial dan ekonomi dan semakin tinggi juga pengetahuan akan kesehatan. Hal ini sejalan dengan penelitian sebelumnya.

\section{Analisis Faktor}

Terlihat dalam Tabel 6 angka angka Factor Loading yang menunjukkan besarnya korelasi suatu variabel dengan faktor yang terbentuk. Berikutnya tahap penentuan variabel - variabel yang akan masuk ke faktor mana, yaitu dengan melakukan perbandingan besar korelasi setiap baris. Berdasarkan hasil dari analisis faktor, dapat diketahui bahwa dari ke 14 variabel yang dianalisis direduksi hanya menjadi 4 faktor yaitu faktor produk $\left(\mathrm{X}_{1}\right)$, harga $\left(\mathrm{X}_{2}\right)$, tempat $\left(\mathrm{X}_{3}\right)$ dan promosi $\left(\mathrm{X}_{4}\right)$. Variabel yang memiliki nilai factor loading terbesar yang membentuk setiap faktor adalah variabel warna daging $\left(\mathrm{X}_{1.1}\right)$ dengan nilai sebesar 0,909, variabel harga terjangkau $\left(\mathrm{X}_{2.1}\right)$ dengan nilai sebesar 0,680, variabel lokasi strategis $\left(\mathrm{X}_{3.1}\right)$ dengan nilai 
sebesar 0,640 dan variabel materi iklan $\left(\mathrm{X}_{4.1}\right)$ dengan nilai sebesar 0,851 .

\section{Analisis Regresi Linier Berganda}

Analisis regresi linier berganda dalam penelitian ini digunakan untuk menjawab hipotesis apakah warna daging, harga yang terjangkau, lokasi strategis, dan materi iklan secara simultan maupun secara parsial berpengaruh terhadap keputusan pembelian. Tabel 7 diperoleh nilai koefisien regresi (constant) sebesar $-1.689,\left(\mathrm{X}_{1.1}\right)$ warna daging 0.725 dan $\left(\mathrm{X}_{4.1}\right)$ materi iklan 0.667. maka persamaan regresi linier berganda yang didapatkan adalah sebagai berikut.

$Y=-1.689+0.725 X_{1}+0.667 X_{4}$

Nilai koefisien determinasi $R$ square $\left(R^{2}\right)$ sebesar 0.570. Hal ini menunjukan bahwa keputusan pembelian dipengaruhi oleh variabel warna daging dan materi iklan.

Uji Hipotesis

Analisis data pada pengujian hipotesis dimaksudkan untuk mengetahui seberapa besar variabel independen mempengaruhi variabel dependen (Irfan, 2015). Analisis ini dilakukan dengan menggunakan uji simultan (uji F) dan uji parsial (uji T).

Uji F dilakukan untuk melihat ada tidaknya pengaruh variabel - variabel bebas (warna daging, harga terjangkau, lokasi strategis dan materi iklan) terhadap variabel terikat (keputusan pembelian) secara bersama - sama.Terlihat pada tabel $7 \mathrm{~F}_{\text {hitung }}$ adalah 31.419, dengan taraf signifikansi $(\alpha)$ $=5 \%, \mathrm{~F}_{\text {tabel }}$ sebesar 2.46, maka $\mathrm{F}_{\text {hitung }}>\mathrm{F}_{\text {tabel }}$. Hal ini menunjukan bahwa $\mathrm{H}_{0}$ ditolak dan $\mathrm{H}_{1}$ diterima. Berdasarkan hal tersebut dapat disimpulkan bahwa warna daging, harga terjangkau, lokasis trategis dan materi iklan berpengaruh secara simultan terhadap keputusan pembelian.

Uji $\mathrm{t}$ dilakukan dengan membandingkan antara nilai $\mathrm{t}$ hitung dengan taraf signifikansi $(\alpha)=5 \%$. Dengan ketentuan tersebut maka diperoleh $\mathrm{t}_{\text {tabel }}$ sebesar1,984. Hasil uji parsial dapat diuraikan sebagai berikut:

Warna daging $\left(\mathrm{X}_{1.1}\right)$ berdasarkan hasil dari uji t pada tabel 7 dapat dilihat bahwa nilai $t_{\text {hitung }}$ sebesar 8.030 dan $t_{\text {tabel }}(\alpha$ $=0,05)$ sebesar 1,984, dimana $8.030>1.984$ dengan nilai signifikan sisebesar 0,000 atau $\mathrm{p}<0,05$ yang artinya ada pengaruh signifikan pada variable warna daging terhadap keputusan pembelian (Hadi. 2012).

Harga Terjangkau $\left(\mathrm{X}_{2.1}\right)$ berdasarkan hasil dari uji t pada tabel 7 dapat dilihat bahwa nilai t hitung sebesar 0.101 dan nilai $\mathrm{t}_{\text {tabel }}(\alpha=0,05)$ sebesar 1,984, dimana 0.101 $<1,984$, dengan nilai signifikansinya sebesar 0,920 atau $\mathrm{p}>0,05$ yang artinya tidak ada pengaruh signifikan variabel harga 
terjangkau terhadap keputusan pembelian (Puryono. 2014).

Lokasi strategis $\left(\mathrm{X}_{3.2}\right)$ berdasarkan hasil dari uji t pada tabel 7 dapat dilihat nilai $\mathrm{t}_{\text {hitung }}$ sebesar 0.775 dan nilai $\mathrm{t}_{\text {abel }}(\alpha=0,05)$ sebesar 1,984 dimana, $0.775<1,984$ dengan nilai signifikansinya sebesar 0,540 atau $\mathrm{p}>$ 0,05 yang artinya tidak ada pengaruh signifikan variabel lokasi strategis terhadap keputusan pembelian (Kholiq. 2017).

Materi iklan $\left(\mathrm{X}_{4.1}\right)$ berdasarkan hasil dari uji $\mathrm{t}$ pada tabel 7 dapat dilihat nilai $\mathrm{t}$ hitung sebesar 7.521 dan nilai $t_{\text {tabel }}(\alpha=0,05)$ sebaesar 1,984 dimana, $7.521>1,984$ dengan nilai signifikansinya sebesar 0,000 atau $\mathrm{p}<0,05$ yang artinya ada pengaruh signifikan variabel materi iklan terhadap keputusan pembelian (Rosanti. 2016).

\section{KESIMPULAN}

Faktor yang paling dominan menentukan keputusan pembelian adalah Warna daging $\left(\mathrm{X}_{1}\right)$ dengan nilai koefisien regresi terbesar yaitu 0,725 .

\section{DAFTAR PUSTAKA}

Burhanudin, A. 2011. Analisis Perilaku Konsumen pada Pembelian Daging Ayam Ras di Pasar Tradisional dan Modern Kota Jember .Skripsi. Universitas Jember.

Gusti I. N. Y. P., M. Sudarmadan dan A. A. Wulandira. 2015. Faktor - faktor yang mempengaruhi masyarakat membeli daging ayam broiler di
Kabupaten Bangli. E. Jurnal Agribisnis dan Agrowisata. 4(1) : 47-55

Hadi AS, Sundjoto. 2012. Pengaruh citra merek dan kesadaran merek terhadap ekuitas citra merek cair dalam kemasan "frisian flag". Media Mahardhika, 11 (1) : 106126.

Hatane., S. 2006. Ekspetasi pelanggan dan aplikasi bauran pemasaran terhadap loyalitas toko modern dengan kepuasan pelanggan sebagai intervening (studi kasus pada Hypermarket Carrefour di Surabaya). Jurnal Manajemen Pemasaran, Fakultas Ekonomi Universitas Kristen Petra, 1(2) : 74-82.

Irfan, A.S. 2015. Pengaruh marketing mix terhadap keputusan pembelian konsumen pada minimarket lulumart di Kota Samarinda. eJournal Administrasi Bisnis, 3(1) : 174-188.

Kharis. 2011. Studi mengenai impulse buying dalam penjualan online. Semarang : Skripsi Universitas Diponegoro.

Khoirul U, dan N. H. Mohammad. 2014. Pengaruh kualitas produk dan kualitas layanan terhadap keputusan pembelian konsumen Indomaret. JEMA, 12(1) : 131142.

Kholiq, N. 2017. Pengaruh kualitas produk, harga dan lokasi terhadap kepuasan pelanggan di Distro East Project di Kediri. Simki Economic, 1(2) : 1-7. 
Puryono T, dan Yuniati. 2014. Pengaruh marketing mix terhadap keputusan pembelian ud gelagah wangi di Magetan. Jurnal Ilmu \& Riset Manajemen, 3(11) : 1-17.

Rosanti E. 2016. Pengaruh harga, promosi dan fasilitas pendukung terhadap keputusan pembelian hotel kini di Pontianak. Bisma, 1(6) :13181326.

Santoso. S. 2004. Mengatasi Berbagai Masalah Statistik Dengan SPSS Versi 11.5. Jakarta: Elex Media Komputindo.

Sayuti, K dan Efendi. 2004. Pola konsumsi pangan sumber protein mahasiswa Universitas Andalas. Jurnal Stigma (2) : 236-243
Setiawan, 2006. Perkembangan konsumsi protein hewani di indonesia: analisis hasil survey sosial ekonomi nasional 2002-2005. Jurnal Ilmu Ternak, 6(1) : 68 - 7 .

Siregar. S. 2013. Statistika Parametrik Untuk Penelitian Kuantitatif Jakarta : PT. Bumi Aksara.

Sugiyono. 2012. Metode Penelitian Kuantitatif Kualitatif dan R\&D. Bandung: Alfabeta. 